DOI: 10.46340/eppd.2020.7.5.12

levgen Romanenko

ORCID ID: https://orcid.org/0000-0003-4115-173X

V. M. Koretsky Institute of State and Law of the National Academy of Sciences of Ukraine, Kyiv

\title{
LEGAL REGULATION OF PROGRAM BUDGETING IN UKRAINE: ANALYSIS OF THE DEVELOPMENT
}

\section{Євген Романенко Інститут держави і права ім. В.М. Корецького Національної академії наук України, м. Kuїв \\ АНАЛІЗ РОЗВИТКУ ПРАВОВОГО РЕГУЛЮВАННЯ ПРОГРАМНОГО БЮДЖЕТУВАННЯ В УКРАЇНІ}

The article studies the issues of legal support of the use of public finances on the basis of program budgeting of state needs and focuses on its implementation in the field of scientific and scientifictechnical activity. The key aspects of the necessary legal framework for this purpose are analyzed, in particular in the parts of application of the program-target method and the state target programs connected with its involvement. The need for measures to improve such legal support has been highlighted. The approaches to this issue in Ukraine and in other countries are compared and the experience of cooperation of its institutions with European partners is generalized. Taking into account the results of the analysis, the ways to normative-legal regulation of some aspects of program budgeting of scientific and scientific-technical activity in Ukraine are outlined.

Keywords: budget sphere, legal support, program-target method, state target program, program budgeting, development of legal regulation, international cooperation.

Постановка проблеми. В багатьох країнах, що нині характеризуються розвиненою економікою, в останні десятиліття відбувалося впровадження програмного бюджетування для забезпечення ефективного використання публічних фінансів, при цьому із залученням програмноцільового методу в розробку і реалізацію наукових і науково-технічних програм, що сприяє, зокрема, досягненню очікуваних результатів, пов'язують значною мірою здобутки таких країн у інноваційному розвитку ${ }^{1}$ В Україні, що $є$ країною 3 перехідною економікою, у цей час були розроблені і прийняті документи, які на законодавчому рівні регламентували використання у бюджетному процесі програмно-цільового методу, наприклад, Закон України від 18 березня 2004 p. № 1621-IV «Про державні цільові програми» ${ }^{2}$, Бюджетний кодекс України від 8 липня 2010 p. № 2456- $\mathrm{VI}^{3}$. Отримала розвитку взаємодія з європейськими партнерами у галузі науки й технологій, що закріпила «Угода між Україною та Свропейським Співтовариством про наукове і технологічне співробітництво», прийнята 04 липня 2002 р. і ратифікована Законом України №368-IV від 25 грудня 2002 р., мета якої, означена у Статті 1 названого документу, передбачає спільну діяльність сторін

\footnotetext{
${ }^{1}$ Стефанин, А.Л. (2008). Мировой опыт применения програмно-целевого подхода в научно-технической сфере. Новости науки и технологий, 3(9). <http://belisa.org.by/ru/izd/stnewsmag/3_2008/art9_9_2008.html> (2020, серпень, 08); Jonkers, K., Zacharewicz, T. (2016). Research Performance Based Funding Systems: a Comparative Assessment. Luxembourg: Publications Office of the European Union. <doi:10.2791/70120https://publications.jrc.ec.europa.eu/repository/bitstream/JRC101043/kj1a27837enn.pdf> (2020, серпень, 08).

2 Закон про державні иільові програми 2004 (Верховна Рада України). Офіційний сайт Верховної Ради України. <http://zakon.rada.gov.ua/laws/show/1621-15> (2020, серпень, 08).

${ }^{3}$ Бюджетний кодекс Украӥни 2010 (Верховна Рада України). Офіиійний сайт Верховної Ради Украйни. <http://zakon5.rada.gov.ua/laws/show/2456-17> (2020, серпень, 08).
} 
в напрямках заохочення і розвитку науково-технічних досліджень та розробок, виходячи із взаємної зацікавленості в них сторін ${ }^{1}$. Була ратифікованою Законом України від 16 вересня 2014 р. № 1678-VII «Угода про асоціацію між Україною, з однієї сторони, та Європейським Союзом, Європейським співтовариством з атомної енергії і їхніми державами-членами, з іншої сторони», яка, зокрема, Статтею 347 закріпила співробітництво сторін у сфері бюджетної політики, націлене на посилення ефективності використання можливостей програмно-цільових підходів у бюджетному процесі, у забезпеченні об'єктивізації аналізу стану виконання бюджетних програм, Статтею 375 - у сфері науки та технологій, орієнтоване на сприяння входженню України до Європейського дослідницького простору, iї просуванню у напрямку прийнятих в Свропейському Союзі положень політики та права, а Статтею 376 -орієнтоване на обмін досвідом у сфері управління науково-дослідними установами ${ }^{2}$. Зважаючи на згадане вище, особливої актуальності набуває питання стосовно розвитку правових засад використання програмно-цільового методу в бюджетній сфері для забезпечення наукової та науково-технічної діяльності в Україні в умовах її європейської інтеграції.

Аналіз останніх досліджень i публікацій. Організаційно-правові питання пов'язані 3 підготовкою і впровадженням державних цільових програм, в основі чого лежить програмноцільовий метод, обговорювали Б.В. Бабін, В.О. Кроленко, А.Г. Чубенко, Д.М. Павлов, О.І. Деревчук, Ю.І. Пивовар; до проблемних аспектів законодавчого регулювання формування та реалізації державних цільових наукових i науково-технічних програм привертали увагу О.С. Попович, Ю.Ф. Шкворець; законодавчі основи в сфері науково-технічної політики у країнах з розвиненою економікою аналізували О.А. Гончаренко, О.В. Каплинський, В.П. Соловйов; на підходах до розвитку механізмів фінансування науки з урахуванням зарубіжного досвіду акцентували увагу T.I. Сфименко, К.В. Павлюк, Я.В. Петраков, А.М. Соколовська; на використанні програмно-цільового методу для фінансування закладів вищої освіти в Україні, наукова діяльність в яких закріплена законодавством, наголошував О.М. Тимченко.

Мета статті. Виходячи 3 наведеного вище метою даної роботи став аналіз сучасного стану розвитку нормативно-правового забезпечення програмного бюджетування в Україні на прикладі такого в науковій та науково-технічній сфері в умовах поглиблення міжнародної співпраці.

\section{Виклад основного матеріалу.}

На сучасному етапі державотворення правові засади бюджетного фінансування наукових досліджень і розробок знайшли відображення в Законі України від 26 листопада 2015 р. № 848-VIII «Про наукову та науково-технічну діяльність», в якому звернемо увагу на такі положення: 1) частиною першою Статті 56 державні цільові наукові та науково-технічні програми визначено як важливі інструменти з вирішення актуальних для держави проблем й забезпечення розвитку пріоритетних напрямків науки й техніки, а частиною другою Статті 56 означено формування $\mathrm{i}$ виконання таких програм відповідно до раніше прийнятого Закону України від 18 березня 2004 p. № 1621-IV «Про державні цільові програми»; 2) серед повноважень Кабінету Міністрів України пунктом 4 частини першої Статті 41 визначено забезпечення розробки та реалізації державних цільових наукових і науково-технічних програм, а пунктом 5 - визначено їх затвердження відповідно до компетенції цього органу; у той же час для інших центральних органів виконавчої влади в межах їх повноважень пунктом 3 частини першої Статті 43 закріплено участь у встановленні пріоритетів для розвитку в державі науки і техніки й відповідних державних цільових наукових та науково-технічних програм, у визначенні державного замовлення в сфері наукової і науково-технічної діяльності; нарешті, місцевим органам виконавчої влади пунктом 1 частини першої Статті 44 передбачено згідно їх компетенції забезпечення реалізації державних наукових та науково-технічних програм; 3) порядок бюджетного фінансування наукової та науково-технічної діяльності включає використання коштів загального фонду державного бюджету у двох напрямках: по перше, як вказано у пункті 1 частини третьої Статті 48, на забезпечення основної діяльності державних наукових установ, що підлягають фінансуванню коштами державного бюджету, а також наукових досліджень в закладах вищої освіти (університетах, академіях, інститутах); по-друге, як позначено у пункті 2 частини третьої Статті 48,

\footnotetext{
${ }^{1}$ Угода між Україною та Свропейським співтовариством про наукове і технологічне співробітництво 2002 (Верховна Рада України). Офіиійний сайт Верховної Ради Украӥни.

<https://zakon.rada.gov.ua/laws/show/994_194\#top> (2020, серпень, 08).

${ }^{2}$ Угода про асочіацію між Украӥною, з однісї сторони, та Європейським Союзом, Свропейським співтовариством з атомної енергї̈ і їхніми державами-членами, з іншої сторони 2014 (Верховна Рада України). Офічійний сайт Верховної Ради Украӥни. <http://zakon.rada.gov.ua/laws/show/984_011\#n2820> (2020, серпень, 08).
} 
на забезпечення визначених на конкурсних засадах наукових і науково-технічних програм й проектів, а також грантів ${ }^{1}$.

Згідно висновку ініційованого у 2016 році Міністерством освіти і науки України незалежного європейського аудиту національної системи досліджень та інновацій України (Peer Review, 2017) фундаментальні наукові дослідження розвиваються в основному в Національній академії наук України і їй виділяється близько 50 \% коштів, передбачених в щорічному Державному бюджеті на сферу науки і технологій, а національним галузевим академіям наук разом - $25 \%{ }^{2}$. У звязку 3 наведеним підкреслимо, що в Законі України від 26 листопада 2015 р. № 848-VIII «Про наукову та науково-технічну діяльність» Статтею 17 Національну академію наук України визначено як вищу в державі наукову самоврядну організацію і наголошено, зокрема, на ії заснуванні на державній власності, на ії статусі державної організації, створеної як неприбуткова державна бюджетна установа, на забезпеченні ії діяльності коштами, що визначаються у Державному бюджеті кожного року окремим рядком, на її статусі головного розпорядника бюджетних коштів ${ }^{3} .3$ часу заснування Академії виділяються два рівні нормативно-правового регулювання iіi особливого статусу (Нагребельний, 2013), а саме: 1) загальнодержавний, в основі якого лежать, зокрема, закони, укази Президента держави, урядові постанови й розпорядження; 2) внутрішньоакадемічний, в основі якого знаходяться такі нормативні документи Академії як іï Статут, рішення іiї Загальних зборів (найвищого органу самоврядування), постанови й розпорядження іiі Президії ${ }^{4}$.

Статут Національної академії наук України (нова редакція), ухвалений ії найвищим органом самоврядування - Загальними зборами Національної академії наук України (постанова від 14 квітня 2016 р. № 2) і зареєстрований у Міністерстві юстиції України (наказ № 2331/5 від 27 липня 2016 р.), серед сфер діяльності Національної академії наук України (далі - НАН України), що фінансуються коштами державного бюджету, визначає такі як, наприклад, формування програмно-цільової та конкурсної тематики наукових досліджень, проведення відбору наукових i науково-технічних проектів на конкурсних засадах, участь у підготовці та виконанні державних цільових програм, а крім того передбачає інтеграцію наукового потенціалу НАН України з таким закладів вищої освіти ${ }^{5}$. Підкреслимо, що останнє кореспондується з пунктом 1 частини другої Статті 66 Закону України від 1 липня 2014 р. № 1556-VII «Про вищу освіту», де до одного з головних напрямків інтеграції закладів вищої освіти і НАН України у науковій та науково-технічній сфері віднесено спільну діяльність з розробки та виконання державних цільових програм економічного і соціального розвитку України 6 .

В НАН України формування тематики наукових досліджень, у тому числі програмно-цільової та конкурсної, і контроль за їх виконанням регламентує затверджений Постановою Президії НАН України від 19 грудня 2018 р. № 339 (зі змінами, внесеними постановою Президії НАН України від 03 липня 2019 р. № 196) «Порядок формування тематики та контролю за виконанням наукових досліджень в Національній академії наук України», при цьому згідно названого документу під програмно-цільовою і конкурсною тематикою мається на увазі така, формування і подальше виконання якої в НАН України відбувається у відповідності до завдань цільових програм наукових досліджень, конкретних наукових та науково-технічних проектів, визначених на підставі проведених НАН України конкурсів (ними можуть бути й ті, що проводяться спільно з представленими в Україні та за їі межами фондами, організаціями), а під програмно-цільовим фінансуванням наукових

\footnotetext{
1 Закон про наукову та науково-технічну діяльність 2015 (Верховна Рада України). Офіційний сайт Верховної Ради України. <https://zakon.rada.gov.ua/laws/show/848-VIII\#Text> (2020, серпень, 08).

${ }^{2}$ Peer Review of the Ukraine Research and Innovation System. Horizon 2020 Policy support facility (2017). Luxembourg: Publications Office of the European Union. doi:10.2777/095726 <https://www.eap-plus.eu/object/ document/36/attach/PSF_Peer_Review_of_the_Ukrainian_R_I_system.pdf> (2020, серпень, 08).

3 Закон про наукову та науково-технічну діяльність 2015 (Верховна Рада України). Офіиійний сайт Верховної Ради України. <https://zakon.rada.gov.ua/laws/show/848-VIII\#Text> (2020, серпень, 08).

${ }^{4}$ Нагребельний, В. (2013). Правовий статус Національної академії наук України: історія, сьогодення, перспективи розвитку. Вісник Національної академії правових наук України, 3 (74), 39-47. <http://visnyk.kh.ua/uk/article/ pravovy-status-natsionalnoyi-akademiyi-nauk-ukrayini-istoriya-sogodennya-perspektivi-rozvitku> (2020, серпень, 08). ${ }^{5}$ Статут Національної академії наук України (нова редакція) 2016 (Національна академія наук України). Офіиійний сайт Національної академї наук Украӥни. 〈http://www.nas.gov.ua/legaltexts/DocPublic/P-160414-2-1.pdf> (2020, серпень, 08).

6 Закон про вищу освіту 2014 (Верховна Рада України). Офіиійний сайт Верховної Ради Украӥни. <https://zakon.rada.gov.ua/laws/show/1556-18\#Техt> (2020, серпень, 08).
} 
досліджень мається на увазі бюджетне фінансування, яке відбувається за результатами проведеного конкурсу (на конкурсних засадах) і спрямовується, зокрема, на наступне: 1) на виконання цільових наукових та науково-технічних програм й тих окремих наукових і науково-технічних проектів, що націлені на реалізацію вкрай важливих для розвитку (пріоритетних) напрямків у відповідних галузях науки і техніки; 2) на здійснення науково-технічних розробок, що за своїм характером належать до категорії найважливіших прикладних; 3) на розв'язання актуальних комплексних проблем, що мають міждисциплінарну складову; 4) на проведення наукової експертизи проектів, нормативноправових актів, державних програм; 5) на виконання наукових і науково-технічних проектів в рамках міжнародної співпраці ${ }^{1}$.

Принципи, покладені в основу розроблення, формування й подальшого виконання цільових наукових і науково-технічних програм і проектів, контролю за їх виконанням, звітності за ними в умовах фінансування таких цільових наукових і науково-технічних програм і проектів за рахунок коштів, що НАН України отримує із загального фонду Державного бюджету, визначає затверджене Постановою Президії НАН України від 19 грудня 2018 р. № 340 «Положення про цільові програми наукових досліджень НАН України і цільові наукові (науково-технічні) проекти НАН України», при цьому в названому документі серед іншого акцентуеться увага на наступному: 1) на організації та проведенні конкурсного відбору цільових наукових і науково-технічних програм і проектів, на строках їх виконання (для цільових програм фундаментальних досліджень термін виконання становить 3-5 років, а прикладних досліджень - зазвичай до 3 років, для цільових проектів термін виконання визначається у 1-3 роки); 2) на основних стадіях розроблення і формування цільової програми, що підлягають затвердженню Президією НАН України, до яких віднесено підготовку концепції такої програми, пропозицій стосовно складу наукової (науково-технічної) ради програми та положення про таку раду, проведення конкурсу на виконання передбачених цільовою програмою наукових (науково-технічних) робіт, а за його результатами формування переліку наукових (науково-технічних) завдань за нею; 3) на складових проекту концепції цільової наукової (науковотехнічної) програми, до яких належать, зокрема: чітке формулювання проблеми, вирішення якої очікується за виконання цільової програми, а також визначення причини появи цієї проблеми й обгрунтоване пояснення можливості ії вирішення саме в рамках цільової програми; мета цільової програми; основні розділи цільової програми; результати, що очікуються за умови виконання цільової програми, й можливість їх комерціалізації або отримання завдяки ним конкретного соціального ефекту у випадку прикладних досліджень; термін виконання цільової програми й щорічний обсяг орієнтовної потреби у їі фінансуванні; 4) на відповідальності за цільове використання коштів, виділених на забезпечення виконання робіт за цільовою програмою або цільовим проектом, керівника тієї установи НАН України, в якій відповідні роботи за цільовою програмою або цільовим проектом виконуються ${ }^{2}$.

В згаданих вище нормативних документах врахована розроблена згідно рішення Загальних Зборів Національної академії наук України від 18 квітня 2013 р. і схвалена Постановою Президії НАН України від 25 грудня 2013 р. № 187 «Концепція розвитку Національної академії наук України на 2014-2023 роки», при цьому названим документом серед іншого передбачено в НАН України наступне: збільшення частки програмно-цільового та конкурсного фінансування з близько $25 \%$ на час розробки документу до $50 \%$ у 2023 році; розвиток запровадження цільових комплексних програм наукових досліджень, а також цільових наукових й науково-технічних проектів; надання пріоритету тим цільовим програмам і проектам, що мають прикладну спрямованість; розвиток міжнародної співпраці й інтегрування у європейський дослідницький простір ${ }^{3}$.

Порівнюючи організацію державного фінансування досліджень i розробок в економічно розвинених країнах Європи, звернемо увагу, що воно включає дві основні складові: базове

\footnotetext{
${ }^{1}$ Порядок формування тематики та контролю за виконанням наукових досліджень в Національній академії наук України 2018 (Національна академія наук України). Офіційний сайт Національної академії наук України. <http://www.nas.gov.ua/legaltexts/DocPublic/P-181219-339-1.pdf> (2020, серпень, 08).

${ }^{2}$ Положення про иільові програми наукових досліджень НАН України і иільові наукові (науково-технічні) проекти НАН України 2018 (Національна академія наук України). Офімійний сайт Національної академії наук України. <http://www.nas.gov.ua/legaltexts/DocPublic/P-181219-340-3.pdf> (2020, серпень, 08).

${ }^{3}$ Кониепиія розвитку Національної академії наук України на 2014-2023 роки 2013 (Національна академія наук України). Офіційний сайт Національної академії наук Украӥни. <http://www.nas.gov.ua/legaltexts/DocPublic/ P-131225-187-1.pdf> (2020, серпень, 08).
} 
(інституційне, організаційне) фінансування, спрямоване на забезпечення діяльності установи, i проектне фінансування, яке орієнтоване на забезпечення виконання відібраного на конкурсних засадах наукового або науково-технічного проекту (дослідження), що має конкретну мету, обгрунтовані план іiі досягнення й оцінку витрат, необхідних для одержання очікуваних результатів у визначений проміжок часу; а за результатами експертної оцінки (Jonkers, \& Zacharewicz, 2016) станом на 2013-2014 рр. в загальному обсязі коштів, виділених державою на дослідження і розробки, саме на проектне фінансування припадало понад 50 \% у Великій Британії, Бельгії, Польщі, Ірландії, Латвії, Чехії, Хорватії, припадало 26-50 \% в Австрії, Швейцарії, Нідерландах, Швеції, Словенії, Литві, Німеччині, Іспанії, Фінляндії, Болгарії, Данії, Норвегії, Греції, а менше 26 \% в Мальті, Італії, Франції.

Виходячи з результатів ініційованого у 2016 році Міністерством освіти і науки України незалежного європейського аудиту національної системи досліджень та інновацій України (Реer Review, 2017) (аудит проводився спеціальною Панеллю «Інструмент політичної підтримки програми «Горизонт 2020», створеною в межах Рамкової програми Європейського Союзу з досліджень та інновацій «Горизонт 2020», для сприяння зусиллям країн-членів та країн-асоційованих членів у реформуванні національних наукової, а також інноваційної сфер), залучені до аудиту фахівці рекомендували розвинути комплексну систему конкурсного фінансування науково-дослідних та дослідно-конструкторських робіт і частку такого фінансування в загальній сумі державних коштів, що виділяються в країні на забезпечення досліджень, довести у 2022 році до $40 \%$, використовуючи при цьому визначені Законом України від 26 листопада 2015 р. № 848-VIII «Про наукову та науковотехнічну діяльність» можливості Національного фонду досліджень України․

Відмітимо, що співробітництво між Україною та Європейським Союзом шляхом участі України у програмі «Горизонт 2020», передбачено Статтею 376 ратифікованої Законом України від 16 вересня 2014 р. № 1678-VII «Угоди про асоціацію між Україною, з однієї сторони, та Європейським Союзом, Європейським співтовариством з атомної енергії і їхніми державами-членами, з іншої сторони» ${ }^{3}$. Його закріпила і конкретизувала «Угода між Україною і Європейським Союзом про участь України у програмі Європейського Союзу Горизонт 2020 - Рамкова програма $з$ досліджень та інновацій (20142020)», учинена 20 березня 2015 р. і ратифікована Законом України № 604-VIII від 15 липня 2015 р. ${ }^{4}$, при цьому названою Угодою визначено статус України упрограмі «Горизонт 2020» в якості асоційованої країни. 3 метою сприяння результативній участі України у вказаній програмі й підвищення інституційної спроможності відповідних цільових груп Естонською Дослідницькою Радою і Міністерством освіти і науки України за партнерської підтримки з боку Міністерства освіти і науки Естонії та НАН України у вересні 2015 року було розпочато спільний проект «Україна у програмі Горизонт 2020», фінансований Міністерством закордонних справ Естонії5.

Для ілюстрації приєднання до програми «Горизонт 2020» розташованих на пострадянському просторі країн, що за класифікацією Організації Об’єднаних Націй відносяться разом з Україною до таких 3 перехідною (транзитивною) економікою ${ }^{6}$, звернемо увагу на згадані вченими в галузі наукознавства (Кавуненко, Черногаєва, \& Вашуленко, 2019) дані станом на січень 2019 року, за якими Україна брала участь тоді у 112 проектах програми «Горизонт 2020», Росія - у 79, Молдова - 40, Білорусь - 36, Грузія 24, Вірменія - 19, Азербайджан - 8, Казахстан - 7, Киргизстан - 6, Узбекистан - 3, Таджикистан - 2,

\footnotetext{
${ }^{1}$ Jonkers, K., Zacharewicz, T. (2016). Research Performance Based Funding Systems: a Comparative Assessment. Luxembourg: Publications Office of the European Union. doi:10.2791/70120

<https://publications.jrc.ec.europa.eu/repository/bitstream/JRC101043/kj1a27837enn.pdf> (2020, серпень, 08).

${ }^{2}$ Peer Review of the Ukraine Research and Innovation System. Horizon 2020 Policy support facility (2017).

Luxembourg: Publications Office of the European Union. doi:10.2777/095726. <https://www.eap-plus.eu/object/ document/36/attach/PSF_Peer_Review_of_the_Ukrainian_R_I_system.pdf> (2020, серпень, 08).

${ }_{3}^{3}$ Угода про асоиіацію між Україню, з однієї сторони, та Європейським Союзом, Свропейським співтовариством з атомної енергії і їхніми держсавами-членами, з іншої сторони 2014 (Верховна Рада України). Офіиійний сайт Верховної Ради України. <http://zakon.rada.gov.ua/laws/show/984_011\#n2820> (2020, серпень, 08).

${ }^{4}$ Угода між Украӥною і Свропейським Союзом про участь Украйни у програмі Європейського Союзу Горизонт 2020 - Рамкова програма з досліджень та інноваиій (2014-2020) 2015 (Верховна Рада України). Офіційний сайт Верховної Ради Украӥни. <https://zakon.rada.gov.ua/laws/show/984_018\#Text> (2020, серпень, 08).

${ }_{5}^{5}$ Горизонт 2020: Рамкова програма ЄС з досліджень та інновацій. Урядовий портал. Сдиний веб-портал органів виконавчої влади України. <https://www.kmu.gov.ua/storage/app/media/uploaded-files/broshura-gorizont2020-1201.pdf> (2020, серпень, 08).

${ }^{6}$ World Economic Situation and Prospects 2020. (2020). New York: United Nations. <https://www.un.org/development/ desa/dpad/wp-content/uploads/sites/45/publication/WESP2020_FullReport_web.pdf> (2020, серпень, 08).
} 
Туркменістан - у 1 проекті ${ }^{1}$. За інформацією Міністерства освіти і науки України станом на липень 2020 року представники України отримали вже 182 гранти за програмою «Горизонт 2020»². Повідомляється про виконання в установах НАН України близько 40 проектів за цією програмою

Серед згаданих вище країн, дотичних до програми «Горизонт 2020», шість (Україна, Молдова, Грузія, Білорусь, Вірменія та Азербайджан) долучені до започаткованої у 2009 році зовнішньополітичної ініціативи Європейського Союзу «Східне партнерство» за участі його 28 держав-членів, одним з напрямків багатовекторної співпраці за якою визначено тематичну платформу, де розгляду підлягають питання освіти і науки ${ }^{4}$, а три країни (Україна, Молдова, Грузія) уклали також і відповідні Угоди про асоціацію з Свропейським Союзом, за якими передбачено наближення норм національного законодавства до таких, прийнятих у цьому міждержавному об'єднанні5. Відмітимо, що в багатьох країнах 3 перехідною (транзитивною) економікою розвивається практика законодавчого закріплення використання програмно-цільового методу в бюджетному процесі національного рівня ${ }^{6}$, що поширюється й на сферу наукової та науковотехнічної діяльності.

Так, Закон Республіки Вірменія від 26 грудня 2000 року № 3Р-119 «Про наукову та науковотехнічну діяльність» - «О научной и научно-технической деятельности» - в Статті 23 закріплює бюджетне фінансування наукової та науково-технічної діяльності у формах базового, програмноцільового і договірного (тематичного) фінансування, а також спрямування, зокрема, програмноцільового фінансування, що розподіляється на конкурсних засадах, на реалізацію державних науковотехнічних програм у пріоритетних для розвитку науки і техніки напрямках ${ }^{7}$. Закон Республіки Казахстан від 18 лютого 2011 року № 407-IV ЗРК (зі змінами і доповненнями станом на 28 жовтня 2019 року) «Про науку» - «О науке» - в Статті 24 закріплює фінансування 3 державного бюджету наукової та (або) науково-технічної діяльності у формах базового, грантового і програмно-цільового фінансування, а в Статті 27 визначає спрямування останнього на вирішення стратегічно важливих для держави завдань й здійснення програмно-цільового фінансування на конкурсних засадах або за наявності відповідного рішення Уряду Республіки Казахстан поза ними ${ }^{8}$. Закон Киргизької

\footnotetext{
${ }^{1}$ Кавуненко, Л.Ф., Черногаєва, О.Г., Вашуленко, О.С. (2019). Інтеграція України та країн СНД у європейський науковий простір: досвід участі у рамкових програмах ЄС. Наука, технології, інновації, 2, 54-66. <http://doi.org/10.35668/2520-6524-2019-2-07> (2020, серпень, 08).

2 Горизонт 2020. Офіційний сайт Міністерства освіти і науки Украӥни. <https://mon.gov.ua/ua/tag/gorizont$2020>(2020$, серпень, 08).

3 Загородній, А.Г. (2020). Звіт про діяльність НАН України з координації міждисциплінарних досліджень, міжнародну співпрацю та роботу з науковою молоддю у 2015-2019 роках. Вісник Національної академії наук України, 5, 62-72. <http://www.visnyk-nanu.org.ua/sites/default/files/files/Visn.2020/5/Visn_5-

2020\%2B9 Zagorodny.pdf > (2020, серпень, 08).

${ }^{4}$ Східне партнерство. Урядовий портал. Сдиний веб-портал органів виконавчої влади Украӥни. <https://www.kmu.gov.ua/diyalnist/yevropejska-integraciya/shidne-partnerstvo> (2020, серпень, 08).

5 Рудік, Н.М. (2016). Угоди про асоціацію між ЄС та Україною, Грузією та Молдовою: спільні риси та відмінності. Публічне адміністрування: теорія та практика, 2 (16). <http://www.dridu.dp.ua/zbirnik/201602(16)/8.pdf> (2020, серпень, 08).

${ }^{6}$ Гудкова, А.А. (2014). Развитие программно-целевого метода планирования исследований и разработок. Инноватика и экспертиза, 1 (12), 121-130. <http://inno-exp.ru/archive/12/innov_12_2014_121-130.pdf> (2020, серпень, 08); Докукина, А.А. (2017). Внедрение бюджетирования, ориентированного на результат, в Республике Беларусь. Управление в социальных и экономических системах: материалы XXVI Международной научно-практической конференции (г. Минск, 18 мая 2017 г.). Минск: Минский инновационный университет, 9-10. <http://elibrary.miu.by/conferences!/item.uses/issue.xxvi/article.2.html> (2020, серпень, 08); Кульевская, Ю.Г., Чултурова, Д.Ш., Улезько, Г.Г. (2015). Программно-целевой метод финансирования и результативность научно-технических программ в Казахстане. Новости науки Казахстана, 1 (123), 20-33.

<http://www.vestnik.nauka.kz/wp-content/uploads/2015/03/2-Кульевская-Програм-цел.-метод-2015-№1-ННК.pdf> (2020, серпень, 08); Мкртчян, Э.А. Аросян, С.А., Акопян, Г.А. (2018). Ключевые аспекты внедрения программного бюджетирования в мире и в Республике Армения. Финансовый журнал, 4, 115-120. doi: 10.31107/2075-1990-2018-4-115-120 <https://www.finjournal-nifi.ru/images/FILES/Journal/Archive/2018/4/ statii_4/10_fm_2018_4.pdf> (2020, серпень, 08).

7 Закон о научной и научно-технической деятельности 2000 (Национальное Собрание Республики Армения). Armenian Legal Information System. <https://www.arlis.am/DocumentView.aspx?docid=63036> (2020, серпень, 08). 8 Закон о науке 2011 (Парламент Республики Казахстан). Информационно-правовая система нормативных правовых актов Республики Казахстан. 〈http://adilet.zan.kz/rus/docs/Z1100000407> (2020, серпень, 08).
} 
Республіки від 16 червня 2017 року № 103 «Про науку і про основи державної науково-технічної політики» - «О науке и об основах государственной научно-технической политики» - в Статті 22 закріплює формування та реалізацію державних науково-технічних програм на базі цільових проектів і розробок, а в Статті 28 визначає фінансування державою наукової та науково-технічної діяльності за рахунок коштів Національного фонду досліджень (його створення передбачено цим Законом) у формах базового, програмно-цільового і грантового фінансування й, зокрема, здійснення за результатами конкурсного відбору програмно-цільового фінансування 3 метою підтримки наукових розробок, що відповідають чинним пріоритетам держави ${ }^{1}$.

Бюджетний Кодекс Республіки Білорусь від 16 липня 2008 № 412-3 - «Бюджетный кодекс Республики Беларусь» ${ }^{2}$ в Статті 87 закріплює, що за використання програмно-цільового методу у бюджетному процесі формування бюджетних витрат має відбуватися, зазвичай, за державними програмами та підпрограмами, причому такі витрати повинні відноситися до категорії програмних. Затверджене постановою Ради Міністрів Республіки Білорусь від 31 серпня 2005 року № 961 (з урахуванням змін і доповнень, внесених постановами Ради Міністрів Республіки Білорусь від 29 жовтня 2007 року № 1411, від 12 березня 2009 року № 305 та від 18 лютого 2013 року № 114) «Положення про порядок розробки і виконання науково-технічних програм»- «Положение о порядке разработки и выполнения научно-технических программ» ${ }^{3}$ важливу роль у питаннях, що стосуються державних, регіональних та галузевих науково-технічних програм, відводить Державному комітету з науки і технології Республіки Білорусь. Нарешті, затверджене Постановою Ради Міністрів Республіки Білорусь від 12 серпня 2010 року № 1196 (в редакції постанови Ради Міністрів Республіки Білорусь від 11 квітня 2018 року № 278) «Положення про порядок розробки, фінансування і виконання державних програм наукових досліджень»- «Положение о порядке разработки, финансирования и выполнения государственных программ научных исследований» ${ }^{4}$ у питаннях організації та методичного забезпечення розробки програм наукових досліджень, конкурсного відбору програм, загальної координації їх виконання, контролю за їх виконанням, прийняття отриманих за ними результатів, подання звітів про виконання програм до Ради Міністрів Республіки Білорусь ключову адміністративно-координуючу роль покладає на Національну академію наук Білорусі.

Звернемо увагу, що в Законі Республіки Білорусь від 5 травня 1998 року № 159-3 «Про Національну академію наук Білорусі» - «О Национальной академии наук Беларуси» 5 в Статті 8 закріплено прийняття актів законодавства, які стосуються питань розвитку науки, за погодження з суб'єктом державної науково-технічної політики Республіки Білорусь - Національною академію наук Білорусі, визначеною в Статті 1 цього Закону вищою державною науковою організацією; а в Законі Киргизької Республіки від 25 липня 2002 року № 132 «Про Національну академію наук Киргизької Республіки» - «О Национальной академии наук Кыргызской Республики» ${ }^{6}$ в Статті 6 закріплено прийняття актів законодавства, які стосуються питань розвитку науки, за безпосередньої участі суб'єкта державної науково-технічної політики Киргизької Республіки - Національної академії

\footnotetext{
1 Закон о науке и об основах государственной научно-технической политики 2017 (Жогорку Кенеш Кыргызской Республики). Централизованный банк данных правовой информации Кыргызской Республики. <http://cbd.minjust.gov.kg/act/view/ru-ru/111606> (2020, серпень, 08).

2 Бюджетный кодекс Республики Беларусь 2008 (Национальное собрание Республики Беларусь). Национальный правовой Интернет-портал Республики Беларусь. <https://etalonline.by/document/?regnum=Hk0800412> (2020, серпень, 08).

${ }^{3}$ Положение о порядке разработки и выполнения научно-технических программ 2005 (Совет Министров Республики Беларусь). Официальный сайт Государственного колитета по науке и технологиям Республики Беларусь. <http://www.gknt.gov.by/deyatelnost/polozhenie-o-poryadke-razrabotki-i-vypolneniya-nauchnotekhnicheskikh-programm.php> (2020, серпень, 08).

${ }^{4}$ Положение о порядке разработки, финансирования и выполнения государственных программ научных исследований 2010 (Совет Министров Республики Беларусь). Официальный сайт Совета Министров Республики Беларусь. <http://www.government.by/upload/docs/file5657fd6d285ae738.PDF> (2020, серпень, 08). 5 Закон о Национальной академии наук Беларуси 1998 (Национальное собрание Республики Беларусь). Национальный правовой Интернет-портал Республики Беларусь. <https://etalonline.by/document/?regnum= h19800159\&q_id=2197284> (2020, серпень, 08).

6 Закон о Наџиональной академии наук Кыргызской Республики 2002 (Жогорку Кенеш Кыргызской

Республики). Централизованный банк данных правовой информаџии Кыргызской Республики.

$<$ http://cbd.minjust.gov.kg/act/view/ru-ru/1089?cl=ru-ru> (2020, серпень, 08).
} 
наук Киргизької Республіки, визначеною в Статті 1 цього Закону вищою державною науковою установою. Названі Академії разом з НАН України та Академіями загальнонаціонального рівня ще 13 держав $€$ повноправними членам започаткованої у 1993 році Міжнародної асоціації академій наук неурядового об'єднання, однією з цілей створення якого стало згуртування зусиль вчених на вирішенні проблемних аспектів наукового розвитку суспільства ${ }^{1}$. Використання міжнародного досвіду законодавчого закріплення згаданих вище повноважень за Національними академіями наук могло би, на нашу думку, сприяти й врегулюванню деяких питань наукової та науково-технічної діяльності в Україні.

Так, виходячи з абзацу другого пункту 2 частини другої Статті 17 Закону України від 26 листопада 2015 р. № 848-VIII «Про наукову та науково-технічну діяльність», де серед закріплених за НАН України повноважень в сфері науково-експертної діяльності позначено, що НАН України, зокрема, «здійснює незалежну наукову оцінку проектів стратегічних, прогнозних та програмних документів» ${ }^{2}$, а також «розробляє пропозиції щодо засад державної наукової і науково-технічної політики» ${ }^{3}$ й крім того «здійснює наукову експертизу проектів законів, державних рішень і програм» ${ }^{4}$, нам вбачається за доцільне доповнення відповідних нормативно-правових актів України положеннями про необхідність обговорення і погодження з Національною академією наук України наступного: 1) проектів концепцій державних цільових наукових і науково-технічних програм, що ініціюються передбаченими законодавством органами; 2) проектів державних рішень в частині програмного бюджетування в сфері наукової та науково-технічної діяльності.

Висновки. Розробка правового забезпечення впровадження програмного бюджетування в державі $\epsilon$ важливим чинником, необхідним для іiі соціально-економічного й інноваційного зростання. Прийняті в Україні законодавчі засади організації бюджетного фінансування наукової та науково-технічної діяльності створюють основу для розвитку правового регулювання у названій сфері. Для забезпечення ефективного використання бюджетних коштів причетними до неї організаціями особливої актуальності набуває удосконалення відповідної нормативно-правової бази в частинах впровадження програмно-цільового методу, підготовки концепцій та формування i реалізації цільових програм, зокрема державного рівня, з урахуванням міжнародного досвіду. При цьому одним з важливих чинників, що в кінцевому результаті сприяє використанню останнього, $\epsilon$ співпраця в галузях бюджетної політики, науки і технологій України з Свропейським Союзом, орієнтована на наближення до його принципів політики й права. В країнах 3 перехідною (транзитивною) економікою, залучених до ініціатив Європейського Союзу в названих галузях, розвивається практика законодавчого закріплення використання в бюджетному процесі програмноцільового методу (у тому числі з метою забезпечення належної ефективності державних цільових програм), яка може бути взятою до уваги при уточненні та конкретизації положень правового забезпечення програмного бюджетування в Україні.

\section{References:}

1. Biudzhetnyi kodeks Ukrainy 2010 [Budget Code of Ukraine 2010] (Verkhovna Rada Ukrainy) [(Verkhovna Rada of Ukraine)]. Ofitsiinyi sait Verkhovnoi Rady Ukrainy [Official site of the Verkhovna Rada of Ukraine]. <http://zakon5.rada.gov.ua/laws/show/2456-17> (2020, August, 08). [in Ukrainian].

2. Byudzhetnyiy kodeks Respubliki Belarus 2008 (Natsionalnoe sobranie Respubliki Belarus) [Budget Code of the Republic of Belarus 2008 (National Assembly of the Republic of Belarus)]. Natsionalnyiy pravovoy Internet-portal Respubliki Belarus [National legal Internet portal of the Republic of Belarus]. <https://etalonline.by/document/?regnum=Hk0800412> (2020, August, 08). [in Russian].

3. Horyzont 2020 [Horizon 2020]. Ofitsiinyi sait Ministerstva osvity i nauky Ukrainy [Official site of the Ministry of Education and Science of Ukraine]. <https://mon.gov.ua/ua/tag/gorizont-2020> (2020, August, 08). [in Ukrainian].

4. Horyzont 2020: Ramkova prohrama YeS z doslidzhen ta innovatsii [Horizon 2020: EU Framework Program for Research and Innovation]. Uriadovyi portal. Yedynyi veb-portal orhaniv vykonavchoi vlady Ukrainy

\footnotetext{
${ }^{1}$ Международная ассоциация академий наук (МААН). Офищиальный сайт Международной ассоџиаиии академий наук. <http://int-maan.by/> (2020, серпень, 08).

2 Закон про наукову та науково-технічну діяльність 2015 (Верховна Рада України). Офіиійний сайт Верховної Ради України. <https://zakon.rada.gov.ua/laws/show/848-VIII\#Text> (2020, серпень, 08).

3 Закон про наукову та науково-технічну діяльність 2015 (Верховна Рада України). Офіиійний сайт Верховної

Ради України. <https://zakon.rada.gov.ua/laws/show/848-VIII\#Text> (2020, серпень, 08).

${ }_{4}^{4}$ Закон про наукову та науково-технічну діяльність 2015 (Верховна Рада України). Офіиійний сайт Верховної Ради України. <https://zakon.rada.gov.ua/laws/show/848-VIII\#Text> (2020, серпень, 08).
} 
[Government portal. The only web portal of the executive authorities of Ukraine].

<https://www.kmu.gov.ua/storage/app/media/uploaded-files/broshura-gorizont-2020-1201.pdf>

(2020, August, 08). [in Ukrainian].

5. Gudkova, A.A. (2014). Razvitie programmno-tselevogo metoda planirovaniya issledovaniy i razrabotok [Development of program-targeted method of research planning]. Innovatika i ekspertiza [Innovation and Expertise], no. 1 (12), 121-130. <http://inno-exp.ru/archive/12/innov_12_2014_121-130.pdf> (2020, August, 08). [in Russian].

6. Dokukina, A.A. (2017). Vnedrenie byudzhetirovaniya, orientirovannogo na rezultat, v Respublike Belarus [Implementation of performance-based budgeting in the Republic of Belarus]. Upravlenie $v$ sotsialnyih $i$ ekonomicheskih sistemah: materialyi XXVI Mezhdunarodnoy nauchno-prakticheskoy konferentsii (g. Minsk, 18 maya 2017 g.) [Management in social and economic systems: materials of the XXVI International Scientific and Practical Conference (Minsk, May 18, 2017)]. Minsk: Minskiy innovatsionnyiy universitet. <http://elibrary.miu.by/conferences!/item.uses/issue.xxvi/article.2.html> (2020, August, 08). [in Russian].

7. Zagorodny, A.G. (2020). Zvit pro diialnist NAN Ukrainy z koordynatsii mizhdystsyplinarnykh doslidzhen, mizhnarodnu spivpratsiu ta robotu z naukovoiu moloddiu u 2015-2019 rokakh [Report on the activities of NAS of Ukraine for the coordination of interdisciplinary research, international cooperation and work with scientific youth in 2015-2019]. Visnyk Natsionalnoi akademii nauk Ukrainy [Visnyk of the National Academy of Sciences of Ukraine], no. 5, 62-72. <http://www.visnyk-nanu.org.ua/sites/default/files/files/Visn.2020/5/Visn_5-2020\%2B9_ Zagorodny.pdf> (2020, August, 08). [in Ukrainian].

8. Zakon o nauke 2011 [Law on Science 2011] (Parlament Respubliki Kazahstan) [(Parliament of the Republic of Kazakhstan)]. Informatsionno-pravovaya sistema normativnyih pravovyih aktov Respubliki Kazahstan. [Information and legal system of normative legal acts of the Republic of Kazakhstan]. <http://adilet.zan.kz/rus/docs/Z1100000407> (2020, August, 08). [in Russian].

9. Zakon o nauke i ob osnovah gosudarstvennoy nauchno-tehnicheskoy politiki 2017 (Zhogorku Kenesh Kyirgyizskoy Respubliki) [Law on Science and on the Foundations of State Scientific and Technical Policy 2017 (Jogorku Kenesh of the Kyrgyz Republic)]. Tsentralizovannyiy bank dannyih pravovoy informatsii Kyirgyizskoy Respubliki [Centralized data bank of legal information of the Kyrgyz Republic]. <http://cbd.minjust.gov.kg/act/view/ru-ru/111606> (2020, August, 08). [in Russian].

10. Zakon o nauchnoy i nauchno-tehnicheskoy deyatelnosti 2000 [Law on Scientific and Scientific-Technical Activities 2000] (Natsionalnoe Sobranie Respubliki Armeniya) [(National Assembly of the Republic of Armenia)]. Armenian Legal Information System [Armenian Legal Information System]. <https://www.arlis.am/DocumentView.aspx?docid=63036> (2020, August, 08). [in Russian].

11. Zakon o Natsionalnoy akademii nauk Belarusi 1998 [Law on the National Academy of Sciences of Belarus 1998] (Natsionalnoe sobranie Respubliki Belarus) [(National Assembly of the Republic of Belarus)]. Natsionalnyiy pravovoy Internet-portal Respubliki Belarus [National legal Internet portal of the Republic of Belarus]. <https://etalonline.by/document/?regnum=h19800159\&q_id=2197284> (2020, August, 08). [in Russian].

12. Zakon o Natsionalnoy akademii nauk Kyirgyizskoy Respubliki 2002 [Law on the National Academy of Sciences of the Kyrgyz Republic 2002] (Zhogorku Kenesh Kyirgyizskoy Respubliki) [(Jogorku Kenesh of the Kyrgyz Republic)]. Tsentralizovannyiy bank dannyih pravovoy informatsii Kyirgyizskoy Respubliki [Centralized data bank of legal information of the Kyrgyz Republic]. <http://cbd.minjust.gov.kg/act/view/ru-ru/1089?cl=ru-ru> (2020, August, 08). [in Russian].

13. Zakon pro vyshchu osvitu 2014 [Law on Higher Education 2014] (Verkhovna Rada Ukrainy) [(Verkhovna Rada of Ukraine)]. Ofitsiinyi sait Verkhovnoi Rady Ukrainy [Official site of the Verkhovna Rada of Ukraine]. $<$ https://zakon.rada.gov.ua/laws/show/1556-18\#Text> (2020, August, 08). [in Ukrainian].

14. Zakon pro derzhavni tsilovi prohramy 2004 [Law on State Target Programs 2004] (Verkhovna Rada Ukrainy) [(Verkhovna Rada of Ukraine)]. Ofitsiinyi sait Verkhovnoi Rady Ukrainy [Official site of the Verkhovna Rada of Ukraine]. <http://zakon.rada.gov.ua/laws/show/1621-15> (2020, August, 08). [in Ukrainian].

15. Zakon pro naukovu ta naukovo-tekhnichnu diialnist 2015 [Law on Scientific and Scientific-Technical Activity 2015 (Verkhovna Rada Ukrainy) [(Verkhovna Rada of Ukraine)]. Ofitsiinyi sait Verkhovnoi Rady Ukrainy [Official site of the Verkhovna Rada of Ukraine]. 〈https://zakon.rada.gov.ua/laws/show/848-VIII\#Text> (2020, August, 08). [in Ukrainian].

16. Kavunenko, L.P., Chernohaieva, O.H., Vashulenko, O.S. (2019). Intehratsiia Ukrainy ta krain SND u yevropeiskyi naukovyi prostir: dosvid uchasti u ramkovykh prohramakh YeS [Integration of Ukraine and the CIS countries into the European scientific space: experience of participation in EU Framework programs]. Nauka, tekhnolohii, innovatsii [Science, Technologies, Innovations], no. 2, 54-66. <http://doi.org/10.35668/2520-6524-2019-2-07> (2020, August, 08). [in Ukrainian].

17. Kontseptsiia rozvytku Natsionalnoi akademii nauk Ukrainy na 2014-2023 roky 2013 [Concept of development of the National Academy of Sciences of Ukraine for 2014-2023 2013] [(Natsionalna akademiia nauk Ukrainy). (National Academy of Sciences of Ukraine)]. Ofitsiinyi sait Natsionalnoi akademii nauk Ukrainy [Official site of the National Academy of Sciences of Ukraine]. <http://www.nas.gov.ua/legaltexts/DocPublic/P-131225-187-1.pdf> (2020, August, 08). [in Ukrainian]. 
18. Kulevskaya, Yu.G., Chulturova, D.Sh., Ulezko, G.G. (2015). Programmno-tselevoy metod finansirovaniya i rezultativnost nauchno-tehnicheskih programm v Kazahstane [Program-targeted method of financing and the effectiveness of scientific and technical programs in Kazakhstan]. Novosti nauki Kazahstana [Science News of Kazakhstan], no. 1 (123), 20-33. <http://www.vestnik.nauka.kz/wp-content/uploads/2015/03/2-КульевскаяПрограм-цел.-метод-2015-№1-ННК.pdf> (2020, August, 08). [in Russian].

19. Mezhdunarodnaya assotsiatsiya akademiy nauk (MAAN) [International Association of the Academies of Sciences (IAAS)]. Ofitsialnyiy sayt Mezhdunarodnoy assotsiatsii akademiy nauk [Official site of the International Association of Academies of Sciences]. <http://int-maan.by/> (2020, August, 08). [in Russian].

20. Mkrtchyan, E.A. Arosyan, S.A., Akopyan, G.A. (2018). Klyuchevyie aspektyi vnedreniya programmnogo byudzhetirovaniya v mire i v Respublike Armeniya [Key aspects of program budgeting implementation in the world and in the Republic of Armenia]. Finansovyiy zhurnal [Financial Journal], no. 4, 115-120. doi: 10.31107/2075-1990-2018-4-115-120<https://www.finjournalnifi.ru/images/FILES/Journal/Archive/2018/4/statii_4/10_fm_2018_4.pdf> (2020, August, 08). [in Russian].

21. Nahrebelnyi, V. (2013). Pravovyi status Natsionalnoi akademii nauk Ukrainy: istoriia, sohodennia, perspektyvy rozvytku [The conceptual foundation of the improvement the legal regulation the activity of the National academy of Science of Ukraine]. Visnyk Natsionalnoi akademii pravovykh nauk Ukrainy [Journal of the National Academy of Legal Sciences of Ukraine], no. 3 (74), 39-47. <http://visnyk.kh.ua/uk/article/pravovy-status-natsionalnoyiakademiyi-nauk-ukrayini-istoriya-sogodennya-perspektivi-rozvitku> (2020, August, 08). [in Ukrainian].

22. Polozhenie o poryadke razrabotki i vyipolneniya nauchno-tehnicheskih programm 2005 [Regulations on the procedure for the development and implementation of scientific and technical programs 2005] (Sovet Ministrov Respubliki Belarus) [(Council of Ministers of the Republic of Belarus)]. Ofitsialnyiy sayt Gosudarstvennogo komiteta po nauke i tehnologiyam Respubliki Belarus [Official site of the State Committee on Science and Technology of the Republic of Belarus]. <http://www.gknt.gov.by/deyatelnost/polozhenieo-poryadke-razrabotki-i-vypolneniya-nauchno-tekhnicheskikh-programm.php> (2020, August, 08). [in Russian].

23. Polozhenie o poryadke razrabotki, finansirovaniya $i$ vyipolneniya gosudarstvennyih programm nauchnyih issledovaniy 2010 [Regulation on the procedure for the development, financing and implementation of state research programs 2010] (Sovet Ministrov Respubliki Belarus) [(Council of Ministers of the Republic of Belarus)]. Ofitsialnyiy sayt Soveta Ministrov Respubliki Belarus [Official site of the Council of Ministers of the Republic of Belarus]. http://www.government.by/upload/docs/file5657fd6d285ae738.PDF> (2020, August, 08). [in Russian].

24. Polozhennia pro tsilovi prohramy naukovykh doslidzhen NAN Ukrainy i tsilovi naukovi (naukovo-tekhnichni) proekty NAN Ukrainy 2018 [Regulations on targeted research programs of the NAS of Ukraine and targeted scientific (scientific and technical) projects of the NAS of Ukraine 2018] (Natsionalna akademiia nauk Ukrainy) [(National Academy of Sciences of Ukraine)]. Ofitsiinyi sait Natsionalnoi akademii nauk Ukrainy [Official site of the National Academy of Sciences of Ukraine]. 〈http://www.nas.gov.ua/legaltexts/DocPublic/P-181219-340-3.pdf> (2020, August, 08). [in Ukrainian].

25. Poriadok formuvannia tematyky ta kontroliu za vykonanniam naukovykh doslidzhen v Natsionalnii akademii nauk Ukrainy 2018 [The order of formation of topics and control over the implementation of scientific research at the National Academy of Sciences of Ukraine 2018] (Natsionalna akademiia nauk Ukrainy) [(National Academy of Sciences of Ukraine)]. Ofitsiinyi sait Natsionalnoi akademii nauk Ukrainy. [Official site of the National Academy of Sciences of Ukraine]. <http://www.nas.gov.ua/legaltexts/DocPublic/P-181219-339-1.pdf> (2020, August, 08). [in Ukrainian].

26. Rudik, N.M. (2016). Uhody pro asotsiatsiiu mizh YeS ta Ukrainoiu, Hruziieiu ta Moldovoiu: spilni rysy ta vidminnosti [Association Agreements between Ukraine, Georgia and Moldova: common features and differences]. Publichne administruvannia: teoriia ta praktyka [Public administration: theory and practice], no. 2 (16). <http://www.dridu.dp.ua/zbirnik/2016-02(16)/8.pdf> (2020, August, 08). [in Ukrainian].

27. Statut Natsionalnoi akademii nauk Ukrainy (nova redaktsiia) 2016 [Charter of the National Academy of Sciences of Ukraine (new edition) 2016 (Natsionalna akademiia nauk Ukrainy) [(National Academy of Sciences of Ukraine)]. Ofitsiinyi sait Natsionalnoi akademii nauk Ukrainy [Official site of the National Academy of Sciences of Ukraine]. <http://www.nas.gov.ua/legaltexts/DocPublic/P-160414-2-1.pdf> (2020, August, 08). [in Ukrainian].

28. Stefanin, A.L. (2008). Mirovoy opyit primeneniya programno-tselevogo podhoda v nauchno-tehnicheskoy sfere [World experience in the application of the program-targeted approach in the scientific and technical sphere]. Novosti nauki i tehnologiy [News of Science and Technologies], no. 3(9). <http://belisa.org.by/ru/izd/stnewsmag/3_2008/art9_9_2008.html> (2020, August, 08). [in Russian].

29. Skhidne partnerstvo [Eastern Partnership]. Uriadovyi portal. Yedynyi veb-portal orhaniv vykonavchoi vlady Ukrainy [Government portal. The only web portal of the executive authorities of Ukraine].

<https://www.kmu.gov.ua/diyalnist/yevropejska-integraciya/shidne-partnerstvo> (2020, August, 08). [in Ukrainian].

30. Uhoda mizh Ukrainoiu i Yevropeiskym Soiuzom pro uchast Ukrainy u prohrami Yevropeiskoho Soiuzu Horyzont 2020 - Ramkova prohrama z doslidzhen ta innovatsii (2014-2020) 2015 [Agreement between Ukraine and the European Union on Ukraine's participation in the European Union program Horizon 2020 - Framework Program for Research and Innovation (2014-2020) 2015] (Verkhovna Rada Ukrainy) [(Verkhovna Rada of Ukraine)]. Ofitsiinyi sait Verkhovnoi Rady Ukrainy [Official site of the Verkhovna Rada of Ukraine]. <https://zakon.rada.gov.ua/laws/show/984_018\#Text> (2020, August, 08). [in Ukrainian]. 
31. Uhoda mizh Ukrainoiu ta Yevropeiskym spivtovarystvom pro naukove i tekhnolohichne spivrobitnytstvo 2002 [Agreement between Ukraine and the European Community on Scientific and Technological Cooperation 2002] (Verkhovna Rada Ukrainy) [(Verkhovna Rada of Ukraine)]. Ofitsiinyi sait Verkhovnoi Rady Ukrainy [Official site of the Verkhovna Rada of Ukraine]. <https://zakon.rada.gov.ua/laws/show/994_194\#top> (2020, August, 08). [in Ukrainian].

32. Uhoda pro asotsiatsiiu mizh Ukrainoiu, z odniiei storony, ta Yevropeiskym Soiuzom, Yevropeiskym spivtovarystvom $z$ atomnoi enerhii $i$ yikhnimy derzhavamy-chlenamy, z inshoi storony 2014 [Association Agreement between Ukraine, of the one part, and the European Union, the European Atomic Energy Community and their Member States, of the other part 2014] (Verkhovna Rada Ukrainy) [(Verkhovna Rada of Ukraine)]. Ofitsiinyi sait Verkhovnoi Rady Ukrainy [Official site of the Verkhovna Rada of Ukraine]. <http://zakon.rada.gov.ua/laws/show/984_011\#n2820> (2020, August, 08). [in Ukrainian].

33. Jonkers, K., Zacharewicz, T. (2016). Research Performance Based Funding Systems: a Comparative Assessment. Luxembourg: Publications Office of the European Union. doi:10.2791/70120 <https://publications.jrc.ec.europa.eu/repository/bitstream/JRC101043/kj1a27837enn.pdf> (2020, August, 08). [in English].

34. Peer Review of the Ukraine Research and Innovation System. Horizon 2020 Policy support facility (2017). Luxembourg: Publications Office of the European Union. doi:10.2777/095726 <https://www.eap-plus.eu/object/ document/36/attach/PSF_Peer_Review_of_the_Ukrainian_R_I_system.pdf> (2020, August, 08). [in English].

35. World Economic Situation and Prospects 2020. (2020). New York: United Nations. <https://www.un.org/development/desa/dpad/wp-content/uploads/sites/45/publication/WESP2020_FullReport_web.pdf> (2020, August, 08). [in English]. 